\title{
Macroprudential policies in an agent-based artificial economy
}

\author{
Marco Raberto $^{\mathrm{a}, 1}$, Andrea Teglio ${ }^{\mathrm{b}}$, Silvano Cincotti ${ }^{\mathrm{a}}$

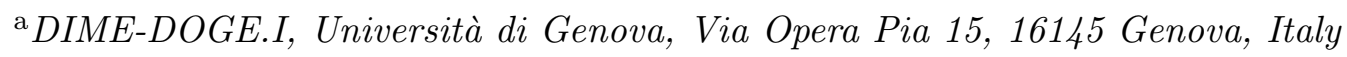 \\ ${ }^{\mathrm{b}}$ Universitat Jaume I, Campus del Riu Sec, 12071 Castellon, Spain
}

\begin{abstract}
Basel III is a recently-agreed regulatory standard for bank capital adequacy with focus on the macroprudential dimension of banking regulation, i.e., the systemwide implications of banks' lending and risk. An important Basel III provision is to reduce procyclicality of present banking regulation and promote countercyclical capital buffers for banks. The Eurace agent-based macroeconomic model and simulator has been recently showed to be able to reproduce a credit-fueled boom-bust dynamics where excessive bank leverages, while benefitting in the short term, have destabilizing effects in the medium-long term. In this paper we employ the Eurace model to test regulatory policies providing time varying capital requirements for banks, based on mechanisms that enforce banks to build up or release capital buffers, according to the overall conditions of the economy. As conditioning variables for these dynamic policies, both the unemployment rate and the aggregate credit growth have been considered. Results show that the dynamic regulation of capital requirements is generally more successful than fixed tight capital requirements in stabilizing the economy and improving the macroeconomic performance.
\end{abstract}

Key words: Basel III, macroprudential regulation, agent-based models and simulation

\section{Introduction}

The recent economic and financial crisis has cast serious doubt on the idea of efficient self-regulating financial and credit markets, and consequently the need for a more effective regulation of these markets unquestionably has arisen. As a response to the crisis, a new global regulatory standard has been proposed

$\overline{1}$ Corresponding author. E-mail: marco.raberto@unige.it 
under the name of Basel III $^{2}$, with the objective to improve the resilience of the banking system.

The rational behind Basel III regulation, which is founded on the same three pillars ${ }^{3}$ characterizing its previous version Basel II, is that one of the main reasons why the economic crisis became so severe was that the banking sectors of many countries had built up excessive on and off-balance sheet leverage. The erosion of the level and quality of the capital base determined that the banking system was not able to absorb systemic trading and credit losses nor could it cope with the large off-balance sheet exposures. The crisis was further amplified by a procyclical deleveraging process. The weaknesses in the banking sector were rapidly transmitted to the rest of the financial system and the real economy, resulting in a massive contraction of liquidity and credit availability (for more details see BIS (2011)).

Some previous works by the authors reproduced these economic mechanisms by means of the agent-based model and simulator Eurace (see Raberto et al (2011); Teglio et al (2012)). In particular, Raberto et al (2011) shows that excessive bank leverages can drive economies into severe recession in the mediumlong run. The pressure on wages and labor costs during credit-fueled economic booms, in conjunction with the speed of growth of credit-money, causes a rise of inflation, that in turn can determine higher interest rates. Excessively indebted firms may be unable to fulfill their financial commitments with the cash proceedings of their revenues, and may be obliged to take new loans to pay interests on their debt, therefore entering in a Ponzi scheme. However, the deterioration of firms creditworthiness causes a further rise of interest rates due to the widening of the risk spread on policy rates. This, in turn, affects the balance sheet of highly indebted firms, which may become soon insolvent. Debt write-offs reduce banks's equity and their lending capacity, thus causing a widespread credit rationing and a forced deleveraging of the corporate sector that may trigger a possible wave of bankruptcies of even good but illiquid firms. A credit-fueled economic boom may thus turn out in a depression.

Given this economic dynamics, emerged in Raberto et al (2011), the aim of this paper is to understand if some of the post-crisis measures proposed by the Basel Committee can have a positive impact in our model.

According to Borio (2011), the institutional response after the crisis has taken two forms. Policymakers have been strengthening the systemic (or macroprudential) orientation of regulatory and supervisory frameworks, and they have begun to question the premise that financial stability can be secured

$\overline{2}$ For details and documents on Basel III, please visit the Bank for International Settlements (BIS) website at: http://www.bis.org/bcbs/basel3.htm

3 The three pillars are: minimum capital requirements, supervisory review process and market discipline. http://www.bis.org/publ/bcbs107.htm 
without a more active support of macroeconomic policies. The established pre-crisis policy framework was focused on the stability of individual institutions (micro-prudential orientation) while the reforms introduced in Basel III provide a macro-prudential approach to regulation and supervision that has a system-wide focus, with the goal to limit the risk of episodes of financial distress with serious consequences for the real economy ("systemic risk").

Claiming that one of the most destabilizing elements of the crisis has been the procyclical amplification of financial shocks throughout the banking system, the new regulation framework introduces some measures in order to make banks more resilient to such procyclical dynamics, like encouraging banks to create countercyclical capital buffers in order to accumulate capital when the economy is strong and use it when the economic conditions are bad. The problem, pointed out again by the Basel Committee in BIS (2011) and also emerged from the computational experiments of Raberto et al (2011), is that losses incurred in the banking sector can be extremely large when a downturn is preceded by a period of excess credit growth. These losses can destabilize the banking sector, creating a credit crunch that contributes to a downturn in the real economy that then feeds back on to the banking sector again.

According to Drehmann et al (2010), the main target of countercyclical capital standards is to encourage banks to build up buffers in good times that can be drawn down in bad ones. In this paper, we design two endogenous adaptive policy rules for the Eurace agent-based model, that set capital requirements in the spirit of encouraging banks to build up capital buffers in good times. Details about the implementation of these policy rules, as identifying bad and good times and choosing the conditioning variables which could guide the build-up and release of capital, are discussed in section 3.1.

The issue of pro-cyclicality in regulatory policy has been widely discussed in the literature of the last 20 years. Blum and Hellwig (1995) already observed that a "rigid link between bank equity and bank lending may act as an automatic amplifier for economic fluctuations, inducing banks to lend more when times are good and to lend less when times are bad, thus reinforcing underlying shocks". They propose a simple stylized macroeconomic model where banks must satisfy a minimum-reserve requirement and a capital adequacy requirement, in order to study the effects of demand disturbance for different levels of capital requirements. Their conclusion, later extended by Cecchetti and $\mathrm{Li}$ (2008) in a more complete economic framework, is that capital requirements have a significant macroeconomic impact. Heid (2007) presents a model with a representative bank which invests in riskless bonds and loans, subject to regulatory constraint, explaining the cyclical effects of capital requirements also in the case of banks which always hold a positive capital buffer. In Raberto et al (2011) and Teglio et al (2012), we addressed similar issues using an agent-based methodology, confirming and extending the 
relevance of the macroeconomic implications of capital requirements. We are both able to reproduce the endogenous amplification of economic fluctuations and to observe how these fluctuation are affected by different levels of capital requirements.

In the last ten years, and markedly after the 2007 crisis, the discussion on bank regulation and pro-cyclicality significantly increased, incorporating new concepts as "systemic risk". Acharya (2009) shows that capital adequacy requirements fail to mitigate systemic risk, using a multi-period general equilibrium model with many agents and markets, inspired to the Allen and Gale (2000) one-period model of bubbles and crisis. In order to assess the cyclaclity of capital requirements, several macroeconometric models have been proposed and estimated on data of different countries. Andersen (2011) and Antão and Lacerda (2011) simulate the IRB (internal rating based) approach of Basel II using Norwegian and Portuguese data respectively, both confirming the cyclicality of capital requirements and comparing the new regulatory framework with the previous one of Basel $\mathrm{I}^{4}$. More recently, in particular after the appearance of Basel III, a discussion about the utility and the correct implementation of macroprudential regulation of the banking sector has arisen. Repullo and Saurina (2011) present a critical assessment of the countercyclical capital buffer in Basel III, evaluating the "conditioning variables" suggested for taking buffer decisions (see Drehmann et al (2010)). Their conclusion is that the choice of the credit-to-GDP gap as the "common reference point" for taking buffer decisions can be misleading because its correlation with the GDP growth is generally negative, and this contradicts the necessity of building buffers of resources in good times that can draw down when conditions deteriorate. They also claim that credit growth "appears to be a much better common reference point for the countercyclical capital buffer". As it will be shown in section 4 our results confirm the efficacy of credit growth as conditioning variable.

In this paper we study the macroeconomic implications of macroprudential policy regulations using an agent-based approach. With respect to the previous literature, mainly consisting in general equilibrium models or macroeconometric models, the Eurace agent-based model and simulator is a much more complex environment where all the economic adjustments are endogenous and produced by the interaction of many heterogeneous agents acting in different markets. The completeness of the Eurace framework is particularly important in this study, where it is necessary to consider the interplay and spillover between the production and financial sector, as well as the credit sector of the economy. In the last decade, several agent-based economic models have been developed in order to focus on the relation between the credit and financial factors and the real economy, see e.g. Delli Gatti et al (2005, 2009); Raberto

\footnotetext{
$\overline{4}$ In Basel II, with respect to Basel I, the capital charges depend on asset quality, based on public or internal ratings, rather than on asset type.
} 
et al (2008a); Dosi et al (2010); Chiarella and Di Guilmi (2011). However, the novelty and the advantage of the Eurace framework is the simultaneous presence of the most important economic agents interacting in many different markets. This feature allows for an endogenous and realistic representation of the whole economic system in an evolving dynamic setting, which has no antecedents in the history of economic modelling.

The paper is divided as follows. Section 1 presents an overview of the general structural features of the Eurace model with the related references. Section 2 reports a detailed description of a new model for capital goods' demand within Eurace, while a throughout description of the implementation of the Basel II capital requirements rule and of the new countercyclical policies is reported in section 3. Computational results are presented and discussed in Section 4, while Section 5 draws our concluding remarks.

\section{An overview of the Eurace model}

Eurace is a model and simulator of an artificial economy which belongs to the class of agent-based computational models (see Tesfatsion and Judd (2006) for a review). The agent-based approach to economics addresses the modelling of economic systems as complex adaptive systems, i.e., systems made by many self-interested interacting units (economic agents here) that may change their behavior in order to adapt to the changing (economic) environment and the change of other units' behavior. The main distinguishing features of an agentbased artificial economy with respect to the mainstream dynamic stochastic general equilibrium (DSGE) modelling can be summarized as follows: out-ofequilibrium dynamics versus market equilibrium, decentralized markets with pairwise bargaining and price dispersion versus centralized markets and the law of one price, adaptive expectations with myopic behavior versus rational expectations and infinite foresight, endogenous shocks and business cycles versus exogenous shocks.

The Eurace artificial economy has been constantly evolving since the start in 2006 of the Eurace project within a EU-funded research grant under the sixth framework programme. Eurace is a fully-specified agent-based model of a complete economy that includes different types of agents and integrates different types of markets. Agents include households which act as consumers, workers and financial investors, consumption goods producers as well as capital goods producers, banks, a government and a central bank. Agents interact in different types of markets, namely markets for consumption goods and capital goods, a labor market, a credit market and a financial markets for stocks and government bonds. Except for the financial market, all markets are characterized by decentralized exchange with price setting behavior on the supply 
side. Agents' decision processes are characterized by bounded rationality and limited information gathering and computational capabilities; thus, agents' behavior follow adaptive rules derived from the management literature for firms and banks, and from experimental and behavioral economics for consumers and financial investors.

In the following, we outline the structural features of the Eurace economy with respect to the agents considered, the types of real and financial assets owned and exchanged by agents as well as the related payment commitments over time. Finally, table 2 presents the balance sheets entries of the Eurace agents. The balance sheets variables can be regarded as the state variables of any agent and, along with wages, interests and prices, are endogenously determined within the system. In particular, wages and consumption goods prices are heterogeneous and fixed by any CGP according to labor market conditions and costs, interest rates are fixed by banks and are heterogeneous as well, because they depend on the creditworthiness of the borrower as well as on the central bank rate ${ }^{5}$; in both cases see Raberto et al (2011); Cincotti et al (2012) for further details. The only exogenous variables is the price of energy (or raw materials) which is considered constant and accordingly the price of capital goods $p_{K}$ which is constant as well, being a fixed mark-up on the energy price. The number of the different types of agents is also fixed.

\subsection{Types of agents}

- Households (Hous) (indexed by $h$ )

- Consumption goods producers (CGP) (also named firms and indexed by $f$ )

- Investment goods producer (KGP)

- Banks (B) (indexed by $b$ )

- Foreign Sector (FgnS)

- Government (Gov)

- Central Bank (CB)

$\overline{5}$ The central bank policy rate is endogenously determined via a Taylor rule 


\begin{tabular}{|c|c|c|c|c|c|c|c|}
\hline & Hous & CGP & KGP & B & FgnS & Gov & $\mathrm{CB}$ \\
\hline Hous & $\begin{array}{c}\text { equity shares } \\
\text { gov. bonds }\end{array}$ & $\begin{array}{c}C \text { GOODS } \\
\text { equity shares } \\
\text { dividends }\end{array}$ & & deposits & & $\begin{array}{c}\text { transfers } \\
\text { gov. bonds } \\
\text { coupons }\end{array}$ & \\
\hline CGP & LABOR & & $K$ GOODS & $\begin{array}{c}\text { loans } \\
\text { deposits }\end{array}$ & & & \\
\hline KGP & & & & deposits & RAW MAT. & & \\
\hline B & & $\begin{array}{l}\text { interests } \\
\text { principal }\end{array}$ & & & & & $\begin{array}{c}\text { loans } \\
\text { deposits }\end{array}$ \\
\hline \multicolumn{8}{|l|}{ FgnS } \\
\hline Gov & taxes & taxes & taxes & taxes & & & seignorage \\
\hline CB & & & & $\begin{array}{l}\text { interests } \\
\text { principal }\end{array}$ & & $\begin{array}{l}\text { bonds } \\
\text { coupons }\end{array}$ & \\
\hline
\end{tabular}

Table 1

Interaction matrix of the Eurace model. The matrix should be read as follows: row agents are the ones demanding or receiving real assets (denoted in SMALL CAPS), financial assets (denoted in bolded style) and their related monetary payment commitments over time (denoted in italics); column agents are the ones supplying the corresponding real assets, financial assets and their related monetary flows

\subsection{Types of Assets}

\subsubsection{Real assets}

- homogeneous consumption goods ( $C$ goods): $(q)$;

- homogeneous capital goods ( $K$ goods): $(K)$;

- homogeneous energy or raw materials;

- homogeneous labor units: $(L)$.

\subsubsection{Financial assets}

- deposits (of households, firms and the KGP) at banks;

- deposits (of banks and the government) at the central bank;

- loans from banks to firms;

- loans from the central bank to banks;

- equity shares (for firms, banks and the capital good producer);

- government bonds.

Agents' behaviors are thoroughly described in our previous works, see e.g. Raberto et al (2011); Teglio et al (2010b); Cincotti et al (2012) about decision making hypotheses in real (consumption goods and labor) markets as well as in credit markets. In particular, consumption goods producers as well as banks are short-term profit maximizers that fix prices (the price of consumption goods and the lending rate) based on a fixed mark-up on their costs (wages 


\begin{tabular}{|c||l|l|}
\hline Agent & Assets & Liabilities \\
\hline \hline Household & $\begin{array}{l}\text { Liquidity } \\
\text { Equity shares } \\
\text { Gov bonds }\end{array}$ & Equity \\
\hline CGP & Capital goods $\left(K^{f}\right)$ & \\
& $\begin{array}{c}\text { Inventories } \\
\text { Liquidity }\end{array}$ & $\begin{array}{l}\text { Loans }\left(D^{f}=\sum_{b} \ell_{b}^{f}\right) \\
\text { Equity }\left(E^{f}\right)\end{array}$ \\
\hline KGP & Liquidity & Equity \\
\hline Bank & Loans $\left(\sum_{f} \ell_{b}^{f}\right)$ & Deposits (Liquidity of Hous, CGP and the KGP) \\
& Liquidity & Standing facility with the CB \\
& Equity \\
\hline Government & Liquidity & $\begin{array}{l}\text { Bonds } \\
\text { Equity }\end{array}$ \\
\hline Central Bank & $\begin{array}{l}\text { Standing facility with Banks } \\
\text { Gov bonds } \\
\text { Liquidity }\end{array}$ & $\begin{array}{l}\text { Outstanding fiat money } \\
\text { Deposits (Liquidity of Banks and the Gov) } \\
\text { Equity }\end{array}$ \\
\hline
\end{tabular}

Table 2

Balance sheets of the agents in the Eurace economy.

and cost of capital for CGPs and the central bank policy rate for banks). CGPs make their production decisions according to standard results from inventory theory (Hillier and Lieberman, 1986). Households' saving-consumption decision is modelled according to the theory of buffer-stock saving behaviour (Carroll, 2001; Deaton, 1992), which states that households consumption depends on a precautionary saving motive, determined by a target level of wealth to income ratio. Households can invest their savings in the asset market, by buying and selling equity shares or government bonds. Households' portfolio allocation is modeled according to a preference structure designed to take into account the psychological findings emerged in the framework of behavioral finance and in particular of prospect theory (Kahneman and Tversky, 1979; Tversky and Kahneman, 1992). Household's behavior in the financial market has been thoroughly described in Raberto et al (2008b); Teglio et al (2009). It is worth noting, however, that only the equity shares of CGPs are exchanged among households in the stock market and only CGPs are allowed to issue new equity shares to be sold to households (see the related cells in the Interaction Matrx in table 1). Equity shares of the KGP as well as of banks are equally distributed among households and can not be traded; put in another way, profits of the KGP and of banks are equaly shared and distributed to households. Finally, the balance sheet approach employed in agent-based modeling, as outlined in table 2 is described in details in Teglio et al (2010a) and in Cincotti et al (2010), where computational experiments about the use of quantitative easing policies have been reported.

The computational experiments reported in this study have been realized within an enriched version of the Eurace model. In particular, beside the new 
regulatory policies designed and investigated in this study, the Eurace model and simulator employed here is characterized by a new model for capital goods demand and a better founded model for the estimation of bankruptcy probability for firms, as described in the following sections.

\section{Capital goods investments}

\subsection{Demand of capital goods}

Physical capital $K$ is employed with labor $L$ by consumption goods producers, henceforth CGPs, to produce an amount of consumption goods $q$ according to a Cobb-Douglas technology, as follows

$$
q=\gamma L^{\alpha} K^{\beta}
$$

where $\gamma$ is positive and constant returns to scale are considered, i.e. $\alpha$ and $\beta$ are positive constants with the constraint $\alpha+\beta=1$. CGPs need new capital goods both to replace capital depreciation and to expand the production capacity. In the previous version of the Eurace model, see e.g. Raberto et al (2011), CGPs computed the desired amount of physical capital, given the planned production quantity, by means of a static optimization method based on the Cobb-Douglas technology and isoquants. In the new model presented here, the demand for capital goods is based on the net present value (NPV) approach, which, according to a recent empirical survey (Graham and Harvey, 2001, 2002), is, along with the internal rate of return (IRR ${ }^{6}$, the most popular method used by managers to evaluate investments. The new investments model should be therefore considered better founded on the realistic behavior of economic actors.

CGPs compute their demand for new capital goods, henceforth investments or $I$, at the beginning of any production month ${ }^{7}$. The amount $I$ of new capital goods will then be delivered and will be ready to use during the next production month. The first step in computing the demand of new capital goods

\footnotetext{
${ }^{6}$ It can be shown, however, that the IRR is generally equivalent to the NPV, except for some special cases.

7 It is worth remembering that 1 month, i.e., 20 business days, is the basic time span for the production process in Eurace and that the starting production day of the month is fixed for each firm but can be different (asynchronous) among different firms.
} 
is the estimation ${ }^{8}$ by every CGP of the expected demand $\widehat{q}^{d}$ of consumption goods it should face during the month. Based on this estimate and on the inventories amount $\mathcal{V}$, the CGP computes the production needs $\bar{q}$ as $\bar{q}=\widehat{q}^{d}-\mathcal{V}$, if $\mathcal{V}<\widehat{q}^{d}$, or $\bar{q}=0$ otherwise. Given the production goal $\bar{q}$, its present capital endowment $K$ and the Coob-Douglas technology, any CGP computes the necessary workforce $L^{d}$ in order to meet the production goal as:

$$
L^{d}=\left(\frac{\bar{q}}{\gamma K^{\beta}}\right)^{\frac{1}{\alpha}} \text {. }
$$

Considering the present workforce $L$, the CGP opens new vacancies, if $L^{d}>L$, or decides layoffs if $L^{d}<L$.

It is worth noting that, if the present workforce $L$ and the present endowment of physical capital $K$ are not sufficient to meet the production goal, i.e., $\bar{q}>\gamma L^{\alpha} K^{\beta}$, increasing the workforce to $L^{d}$ is the only feasible way to meet the production goal during the present month. The reason is that the new demanded physical capital would be available to the CGP only from the next month. Nevertheless, the expected demand $\widehat{q}^{d}$ is still used to determine the demand of new capital goods. The rationale is that the CGP has to check if the increase of the stock of physical capital to meet the production goal, given the present workforce, is profitable in the reasonable hypothesis that $q^{d}$ would be a lower bound for demand in the future.

If $\bar{q}>\gamma L^{\alpha} K^{\beta}$, the CGP computes the desired endowment of physical capital $K^{d}$ as follows:

$$
K^{d}=\left(\frac{\bar{q}}{\gamma L^{\alpha}}\right)^{\frac{1}{\beta}}
$$

The difference $K^{d}-K$ is a reference point for investments. It is worth noting, however, that according to the realistic hypothesis of imperfect capital markets in Eurace and according to the difference between internal and external financing for producers, we stipulate, in line with Fazzari et al (2008), that cash flows are a bound for nominal investments and we consider last month CGP revenues as a proxy for cash flows.

The CGP computes the NPV using a grid of investment values $I$ in the range between 0 and $I_{\max }$, where $I_{\max }$ is given by the minimum between $K^{d}-K$ and last months revenues divided by the price of capital $p_{K}$, set by the capital

\footnotetext{
8 The estimate is based on a linear interpolation of the sales made during a given number of previous months.
} 
good producer ${ }^{9}$.

The NPV is computed considering the present cost of investments, i.e., $p_{K} I$ and the discounted values of the future cash flow given by the augmented productive capacity.

In particular, we consider

$$
N P V(I)=-p_{K} I+\sum_{m=1}^{m^{*}} \frac{\hat{p}_{C}^{m} \Delta q_{C}^{m}}{\left(1+\frac{r}{12}\right)^{m}}
$$

where $\widehat{p}_{C}^{m}$ is the expected consumption goods price level ${ }^{10}$ at month $m, r$ is the weighted average yearly cost of capital for the CGP, and $\Delta q_{C}^{m}$ is the additional amount of monthly production given by the capital investment $I$, after properly taking into account the depreciation given by $\xi$, i.e.,

$$
\Delta q_{C}^{m}=\gamma L^{\alpha}\left(K+(1-\xi)^{(m-1)} I\right)^{\beta}-\gamma L^{\alpha} K^{\beta} .
$$

The end value $m^{*}$ of the sum is given by the number of months when investment is still higher than a given threshold after considering the monthly depreciation rate $\xi$. The CGP demands the amount $I$ of capital goods that maximizes the $N P V(I)$. If $N P V(I)<0$ for any $I$ in the grid, no investment should be done. Finally, it is worth remembering that CGPs are never rationed in the demand for capital goods; however, they may be obliged to reduce the investment schedule because rationed in the credit market.

\subsection{Supply of capital goods}

Capital goods are offered with infinite supply by a single capital goods producer (KGP), which follows a build to order production approach. No inventories and financing needs are then considered for the KGP. Energy and raw materials are the only factor of production and are assumed to be imported from abroad. The price of energy and raw materials is exogenously given and set to a constant value. The price of capital goods $p_{K}$ is a fixed mark-up on energy prices and therefore is also constant in this setting. Profits of the capital good producer are distributed in equal shares among all households. Put differently, it is assumed that all households own equal shares of the capital

$\overline{9}$ See e.g. Raberto et al (2011) for some details about the stylized modeling of capital goods producers in Eurace.

${ }^{10}$ As common in agent-based computational models, the approach is the one of adaptive expectations. Expected inflation is then computed based on past inflation, measured in a given moving time window. 
goods producer and that shares are not traded in any market. Therefore, the amount payed by consumption goods producers for capital goods is partially (the part related to mark-up) channeled back into the economy, while the part related to energy costs leaves the Eurace economy.

\section{Credit financing of investments}

Consumption goods producers face the liquidity needs necessary to finance the production and investment plans as well as the scheduled financial payments, i.e. interests, debt installments, taxes and dividends. They decide between internal and external capital according to the pecking-order theory (Myers and Majluf, 1984), which states that, because of information asymmetries present in both credit and equity markets, firms prefer to meet their financial payments first by using their internal liquidity, then by means of new debt, if liquidity is not sufficient, then by issuing new equity if rationed in the credit market.

It is worth noting that if the producer is unable to meet its financial payments, it goes into bankruptcy. Two types of bankruptcies are considered, i.e., insolvency and illiquidity bankruptcies. The first type is when CGP's equity goes negative. The second type is when the CGP is unable to pay its financial commitments but still owns a positive equity. The significative difference between the two types of bankruptcies is that, in case of insolvency bankruptcy, CGP's debt is restructured, i.e. the debt is reduced to a target fraction of CGP's total assets and the corresponding loans in the portfolios of lending banks are written-off s for the banks' equity. When a CGP goes into bankruptcy, either of the insolvency or of the illiquidity type, it fires all its employees, stopping production for a period necessary to raise new equity capital in the stock market in order to further strengthen its capital base and increase its liquidity.

In the following, we will discuss in detail how the supply of credit is determined within the banking sector.

\subsection{Credit supply}

Credit to consumption goods producers is provided by banks, who are supposed to be short-term profits maximizers. Households deposits are not rewarded and interests due to loans from the central bank are the only costs for banks. Given the positive difference between the lending rate to the corporate sector and the central bank rate, banks can always increase their profits by 
increasing their lending. Banks are then supposed to always fulfil loan requests if regulatory constraints are satisfied, i.e. if capital requirements are met. In particular, following the Basel II capital adequacy rules, we stipulate that a minimum percentage of the risk-weighted loan portfolio should be held by the bank in the form of equity capital as a buffer for possible loan write-offs and equity losses. We denote this minimum percentage as $\kappa$ and we call it capital requirement. The risk weight $\omega^{\lambda}$ of any loan $\lambda$ depends on the borrower credit worthiness after the loan and is measured by using its balance sheet entries. Let us suppose that a bank $b$, with equity $E^{b}$ and risk weighted loan portfolio $W^{b}$, receives a loan request amount $\lambda^{f}$ from CGP $f$, characterized by debt $D^{f}$ and equity $E^{f}$, then the bank is allowed to lend to the CGP an amount $\ell^{b f} \leq \lambda^{f}$ given by:

$$
\ell^{b f}=\left\{\begin{array}{cll}
\lambda^{f} & \text { if } \quad E^{b} \geq \kappa\left(W^{b}+\omega^{\lambda} \lambda^{f}\right), \\
\frac{E^{b}-\kappa W^{b}}{\kappa \omega^{\lambda}} & \text { if } \quad \kappa W^{b}<E^{b}<\kappa\left(W^{b}+\omega^{\lambda} \lambda^{f}\right), \\
0 & \text { if } \quad E^{b} \leq \kappa W^{b} .
\end{array}\right.
$$

The rationale of the rule is that the bank is allowed to lend up to the amount $\ell^{b f}$ that, weighted by the loan riskiness $\omega^{\lambda}$ and summed to its present risky weighted portfolio $W^{b}$, can be sustained by its equity base $E^{b}$, which should be at least $\kappa \%$ of $W^{b}+\omega^{\lambda} \ell^{b f}$. The loan riskiness $\omega^{\lambda}$ is computed by considering first the borrower's default probability, along the lines of the Moody's KMV model (Saunders and Allen, 2010), then by adopting an ad-hoc approximation of the so-called Basel II internal ratings approach that, given the credit rating of the borrower (here given by the default probability), provides the loan riskiness $\omega^{\lambda}$. In particular, inspired by the Moody's KMV model (Saunders and Allen, 2010), we consider the balance sheet entries of the borrower as an indicator of its distance to default or, alternatively, probability of default and credit rating. In this context, the probability of default $\pi^{f}$ of borrower $f$ is defined as:

$$
\pi^{f}=\frac{D^{f}+\lambda^{f}}{D^{f}+\lambda^{f}+E^{f}}
$$

where the rationale is that the lower is the capital base of the borrower with respect to its debt, the higher is the likelihood of default, because of possible equity losses due to negative earnings. We then stipulate that the risk weight of the loan depends on $\pi^{f}$ through an ad-hoc function as follows:

$$
\omega^{\lambda}=2.5\left(\pi^{f}\right)^{3} .
$$

This particular cubic function has to be considered as an approximation of the so-called Basel II internal ratings approach, after considering its graphical 
representation as in Yeh et al (2005)[Figure 2].

\subsection{Adaptive minimum capital requirements}

Following the recommendations of the Basel committee, we implement into the model a mechanism to encourage ${ }^{11}$ banks to build up and release capital buffers, according to the overall economic conditions of the economy, that are generally identified with "bad times" and "good times". The main idea is that in "good times" banks should build up a precautionary capital buffer and release it in bad times when credit is scarcely available. The concept of good and bad times is clearly related with expansion and contraction of the economic cycle, but the tricky part is to chose the conditioning variable that permits to identify if times are good or bad. Several possibility has been already suggested. Drehmann et al (2010) suggest three typologies of conditioning variables. The first one includes measures of the aggregate macroeconomic conditions (GDP growth, banks and non banks credit growth, or their ratio), the second one focuses on the banking sector activity (banks aggregate profits and losses, banks credit growth), while the last one is related to the cost of funding for banks (spreads and cost of liquidity). We chose to use in our study a conditioning variable for each of the first two typologies, the unemployment rate as a measure of aggregate macroeconomic conditions and aggregate banks loans as a measure of the banking sector activity.

The first rule for setting the minimum capital requirement $\kappa$ is a piecewise linear rule that maps the unemployment rate into $\kappa$. The logic is that the capital requirement should be tighter when we are in "good times" (low unemployment rate) while should be more relaxed when we are in "bad times" (high unemployment rate). The capital requirement ${ }^{12} \kappa_{t}^{u}$ is then given by:

$$
\kappa_{t}^{u}=\left\{\begin{array}{l}
\kappa_{\max }-\left(\kappa_{\max }-\kappa_{\min }\right) \frac{u_{t}}{\bar{u}} \text { if } u_{t}<\bar{u} \\
\kappa_{\min } \text { if } u_{t} \geq \bar{u}
\end{array}\right.
$$

We use the notation $\kappa_{t}^{u}$ here to highlight the dependence on time and on

${ }^{11}$ Let us note that we are more "compelling" that encouraging banks, because our mechanism cyclically moves minimum capital requirements, as shown in equation 9 and 10. This may be questionable (see Repullo et al (2010); Repullo and Saurina (2011); Gordy (2009)) but it appears to us an acceptable simplification, considering that in the model banks only have loans as risky assets in their portfolio

${ }^{12}$ We omit the adjective "minimum" here to avoid confusion between $\kappa_{t}^{u}$ that is the minimum level of capital required to banks at time $t$, and $\kappa_{\text {min }}$ that is the minimum level under which the time varying $\kappa$ can not drop, and that is independent from time 
the unemployment rate. The values of $\kappa_{t}^{u}$ then lies in an interval between a minimum level $\kappa_{\text {min }}$, reached when the unemployment is higher than a given threshold $\bar{u}$, and a maximum value $\kappa_{\max }$ that is assumed at full employment. In the computational experiments presented here, we have set $\kappa_{\min }=8 \%$, which is the the actual reference in the Basel II accords, $\kappa_{\max }=12 \%$ and $\bar{u}=25 \%$. The parameter $\bar{u}$ determines the slope of the straight line in the $\left(u_{t}, \kappa_{t}^{u}\right)$ plane, and represents the threshold unemployment rate above which the maximum leverage is set to $\kappa_{\text {min }}$.

The mechanism of the second rule is essentially the same as the previous one, using the aggregate loan portfolio of all banks as the conditioning variable. If $L_{t}$ is the sum of all outstanding bank loans at month $t$, the decision making about capital requirement is made according to:

$$
\kappa_{t}^{c}=\left\{\begin{array}{l}
\kappa_{\min }+\left(\kappa_{\max }-\kappa_{\min }\right) \frac{u_{t}}{\bar{u}} \text { if } \frac{\Delta L_{t}}{L_{t}}<\eta, \\
\kappa_{\max } \text { if } \frac{\Delta L_{t}}{L_{t}} \geq \eta .
\end{array}\right.
$$

where $\Delta L_{t} / L_{t}$ is the percentage increase (or decrease) of aggregate credit $L$ from month $t-1$ to month $t$. The parameter $\eta$ represents in this case the threshold monthly credit growth above which $\kappa_{t}^{c}$ is set to $\kappa_{\max }$. The notation is $\kappa_{t}^{c}$ to highlight the dependence on time and on the unemployment rate. In the set of simulations presented in this paper, $\eta=5 \%$, i.e., if monthly credit growth is higher that $5 \%$, capital requirement is the maximum one $(12 \%)$. The rationale behind the rule is again to force banks to build up buffers in good times, which are usually characterized by a rapid growth of credit, that can be drawn down in bad ones. Buffers should be understood as capital in excess that is available to absorb losses in bad times. Real world experience as well as Eurace simulations have showed that a too rapid credit growth, while benefitting in the short term, can result in a bubble burst in the long run, when high levels of leverage become unsustainable. In this perspective, this new rule for $\kappa_{t}^{c}$ can also be interpreted on one hand as a way to moderate a too rapid growth of credit by increasing the minimum requirements of capital for banks and, on the other hand, as an attempt to prevent the effects of banks's loans write-off on the credit supply. Finally, it is worth noting that whatever the negative value $\Delta L_{t} / L_{t}$ can be, we stipulate that capital requirement can never drop under the minimum level of $\kappa_{\min }$, set to $8 \%$.

\section{Computational experiments}

We present in this section several tables resuming the average values (with relative standard errors) of some of the main economic indicators in order to 


\begin{tabular}{|c|c|c|c|c|c|}
\hline$\kappa(\%)$ & $\begin{array}{c}\text { cons. goods } \\
\text { production }\end{array}$ & $\begin{array}{c}\text { inv. goods } \\
\text { production }\end{array}$ & $\begin{array}{c}\text { unempl. } \\
\text { rate (\%) }\end{array}$ & $\begin{array}{c}\text { banks' } \\
\text { loans }\end{array}$ & $\begin{array}{c}\text { firms' } \\
\text { leverage }\end{array}$ \\
\hline \hline 8 & $9629(25)$ & $1620(14)$ & $2.84(0.18)$ & $151393(1042)$ & $3.21(0.02)$ \\
10 & $9530(29)$ & $1530(18)$ & $2.86(0.18)$ & $143659(1090)$ & $2.85(0.02)$ \\
12 & $9486(27)$ & $1486(14)$ & $2.88(0.18)$ & $138126(840)$ & $2.60(0.01)$ \\
$\kappa_{t}^{u}$ & $9411(40)$ & $1442(24)$ & $2.95(0.20)$ & $136749(1246)$ & $2.58(0.02)$ \\
$\kappa_{t}^{c}$ & $8518(57)$ & $1069(12)$ & $7.54(0.57)$ & $121650(512)$ & $2.23(0.01)$ \\
\hline
\end{tabular}

Table 3

Values of the main economic indicators in the first 5 years of simulation for different capital requirements $(\kappa)$. An unemployment rule $\kappa_{t}^{u}($ average value $=11.54)$ and a credit rule $\kappa_{t}^{c}$ (average value $\left.=9.65\right)$ has been used to set dynamic requirements. Values are averaged over 20 different random seeds (standard errors are in brackets)

compare the overall performance of the artificial economy for the three different values of minimum capital requirement. In the same tables we also present the values of the same economic indicators in the two implemented cases of macro-prudential policy, i.e., a countercyclical buffer capital mechanism that uses the unemployment rate as conditioning variable, as shown in eq. 9, and a second one based on banks credit growth, as in eq. 10. Moreover, consistently with the presentation plan adopted in Raberto et al (2011), we separate the simulations into two time periods. The first period shows the first 5 years of simulation while the second period represents the remaining 25 years.

Even in a different setting, results are in agreement with the explications discussed in Raberto et al (2011). When capital requirement is low the economic performance is good in the short term, due to the major amount of credit granted by banks, but bad in the long term because of the augmented financial fragility of firms that leads to a higher risk of insolvency. This mechanism

Table 4

\begin{tabular}{|c|c|c|c|c|}
\hline$\kappa(\%)$ & $\begin{array}{c}\text { cons. goods } \\
\text { production }\end{array}$ & $\begin{array}{c}\text { inv. goods } \\
\text { production }\end{array}$ & $\begin{array}{c}\text { real GDP } \\
\text { level }\end{array}$ & $\begin{array}{c}\text { unempl. } \\
\text { rate (\%) }\end{array}$ \\
\hline \hline 8 & $14296(160)$ & $3650(188)$ & $17946(333)$ & $8.1(0.5)$ \\
10 & $14637(126)$ & $3460(154)$ & $18097(243)$ & $7.6(0.4)$ \\
12 & $15081(154)$ & $3729(137)$ & $18810(270)$ & $6.2(0.4)$ \\
$\kappa_{t}^{u}$ & $15040(157)$ & $3686(131)$ & $18727(270)$ & $5.5(0.5)$ \\
$\kappa_{t}^{c}$ & $15419(151)$ & $3901(103)$ & $19320(224)$ & $3.2(0.4)$ \\
\hline
\end{tabular}

Values of real variables in the last 25 years of simulation for different capital requirements $(\kappa)$. An unemployment rule $\kappa_{t}^{u}$ (average value $=11.34$ ) and a credit rule $\kappa_{t}^{c}$ (average value $=9.61$ ) has been used to set dynamic requirements. Values are averaged over 20 different random seeds (standard errors are in brackets) 


\section{Table 5}

\begin{tabular}{|c|c|c|c|c|}
\hline$\kappa(\%)$ & $\begin{array}{c}\text { price } \\
\text { index }\end{array}$ & $\begin{array}{c}\text { inflation } \\
\text { rate (\%) }\end{array}$ & $\begin{array}{c}\text { wage } \\
\text { index }\end{array}$ & $\begin{array}{c}\text { interest } \\
\text { rate }(\%)\end{array}$ \\
\hline \hline 8 & $1.53(0.03)$ & $5.92(0.20)$ & $6.76(0.13)$ & $8.41(0.21)$ \\
10 & $1.53(0.02)$ & $6.12(0.23)$ & $6.84(0.09)$ & $8.61(0.23)$ \\
12 & $1.55(0.02)$ & $6.33(0.17)$ & $7.03(0.12)$ & $8.82(0.15)$ \\
$\kappa_{t}^{u}$ & $1.51(0.02)$ & $6.22(0.21)$ & $6.97(0.12)$ & $8.58(0.14)$ \\
$\kappa_{t}^{c}$ & $1.43(0.02)$ & $6.13(0.12)$ & $7.27(0.15)$ & $6.90(0.25)$ \\
\hline
\end{tabular}

Values of price variables in the last 25 years of simulation for different capital requirements $(\kappa)$. An unemployment rule $\kappa_{t}^{u}$ (average value $\left.=11.34\right)$ and a credit rule $\kappa_{t}^{c}$ (average value $=9.61$ ) has been used to set dynamic requirements. Values are averaged over 20 different random seeds (standard errors are in brackets)

\begin{tabular}{|c|c|c|c|c|c|}
\hline$\kappa(\%)$ & $\begin{array}{c}\text { total } \\
\text { loans }\end{array}$ & $\begin{array}{c}\text { banks' } \\
\text { equity }\end{array}$ & $\begin{array}{c}\text { firms' } \\
\text { leverage }\end{array}$ & $\begin{array}{c}\text { illiquidity } \\
\text { bankrupt. }\end{array}$ & $\begin{array}{c}\text { insolvency } \\
\text { bankrupt. }\end{array}$ \\
\hline \hline 8 & $720375(25922)$ & $78003(4331)$ & $7.19(0.85)$ & $11.0(0.5)$ & $4.5(0.2)$ \\
10 & $681196(23748)$ & $93022(4280)$ & $6.74(0.58)$ & $8.3(0.4)$ & $4.2(0.1)$ \\
12 & $722717(25495)$ & $117812(5448)$ & $7.12(1.26)$ & $7.4(0.4)$ & $4.1(0.2)$ \\
$\kappa_{t}^{u}$ & $698161(17714)$ & $105051(3474)$ & $6.76(1.55)$ & $9.0(0.4)$ & $3.8(0.1)$ \\
$\kappa_{t}^{c}$ & $590332(10978)$ & $53261(1841)$ & $5.69(3.31)$ & $15.1(0.8)$ & $0.6(0.1)$ \\
\hline
\end{tabular}

Table 6

Values of risk signaling variables in the last 25 years of simulation for different capital requirements $(\kappa)$. An unemployment rule $\kappa_{t}^{u}$ (average value $=11.34$ ) and a credit rule $\kappa_{t}^{c}$ (average value $=9.61$ ) has been used to set dynamic requirements. Columns 4 and 5 show the annual bankruptcy probability for a firm. Values are averaged over 20 different random seeds (standard errors are in brackets)

closely mimics what is reported in BIS (2011), i.e., that banks capital losses "can destabilize the banking sector, which can bring about or exacerbate a downturn in the real economy. This in turn can further destabilize the banking sector...". This is exactly what happens in our model. In the short run real consumption, employment and investments (and therefore real GDP) are higher for loose capital requirements, due to the easier access to bank loans. However a worrying element is already present in the short run: firms leverage increases when relaxing capital requirement, raising economy's financial fragility (or systemic risk). Table 3 corroborates this narrative with the proper economic indicators. To observe the vicious circle between banking sector and real economy, emphasized by BIS (2011), we have to move to the medium-long run. Table 4 shows that the hierarchy emerged in the short run is completely reversed. Tighter capital requirements allow for better economic performances in the long run, in terms of consumption goods production, unemployment 

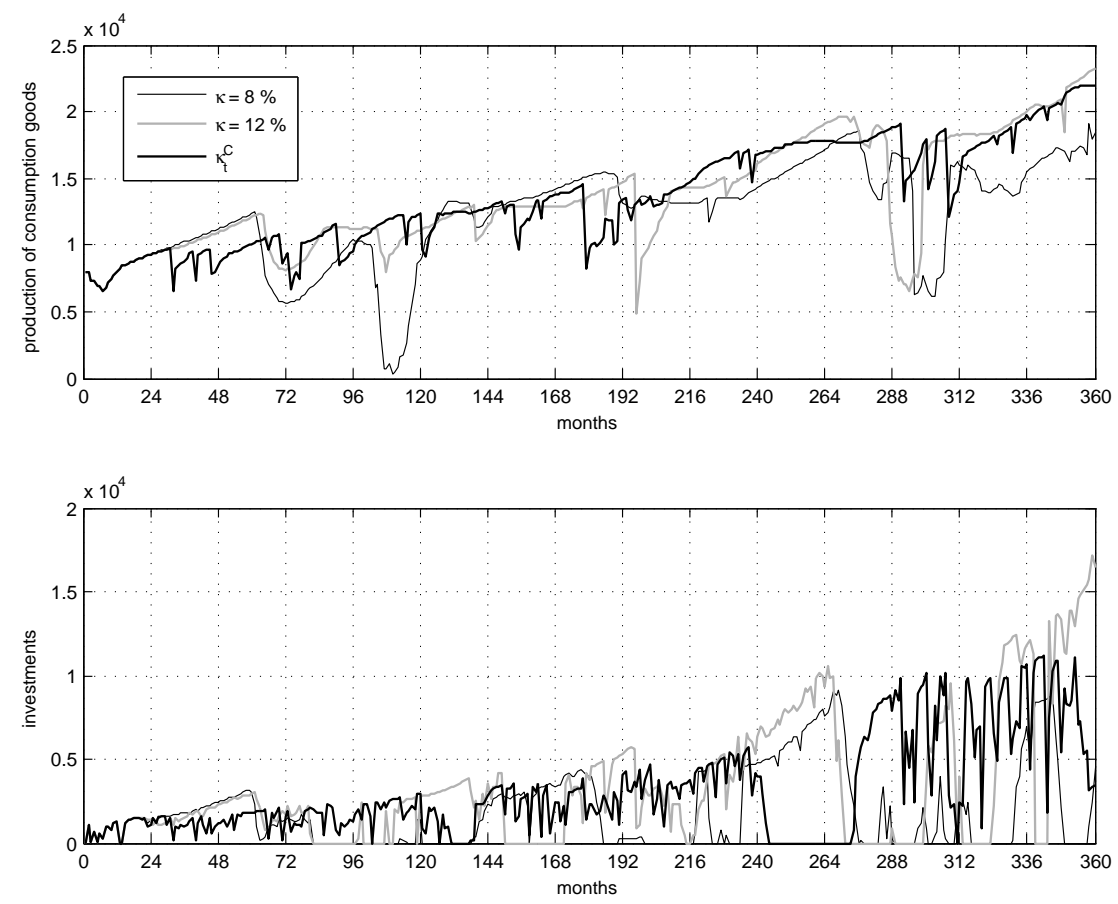

Fig. 1. Time evolution of GDP components. Two lines correspond to different fixed values for minimum capital requirement $\kappa$, while the third one represents the outcome of the capital buffer rule based on credit growth as conditioning variable $\left(\kappa_{t}^{c}\right)$.

rate and real GDP level. Basically, loose capital requirements tend to push firms towards an unbalanced debt-equity ratio, with excess of debt. This can be observed in figure 5, where firms leverage is plot for a sample case. The higher financial fragility of firms determines a higher probability for firms to get into insolvency bankruptcy, as shown in table 6 , with obvious damage for commercial banks equity capital (see figure 4) that undermines the resilience of the banking system. Banks capital losses trigger in turn a credit contraction that prevents firms to roll over debt, therefore exacerbating the downturn in the real economy thought chains of illiquidity bankruptcies. In table 6 it can be observed a clear trend for banks equity and firms insolvency bankruptcies, showing that these economic indicators deteriorate when relaxing capital 

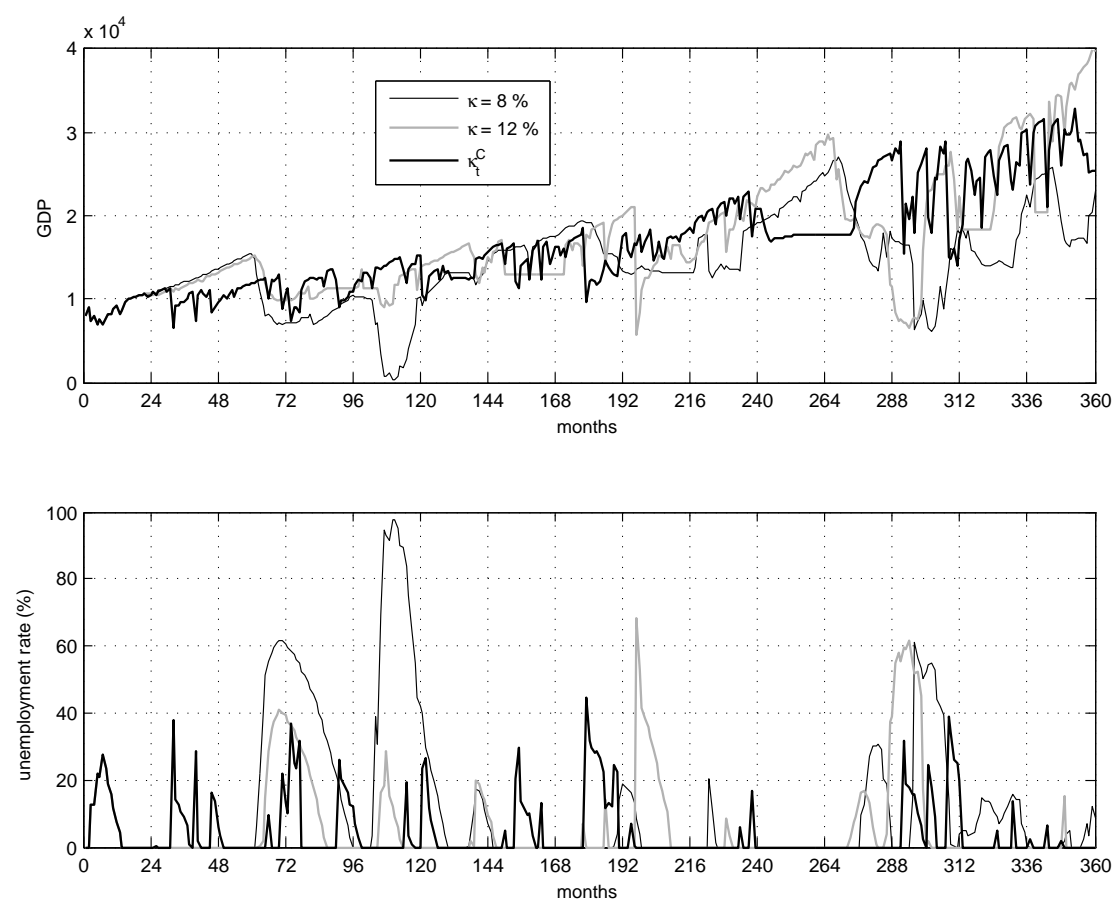

Fig. 2. Time evolution of GDP and unemployment rate. Two lines correspond to different fixed values for minimum capital requirement $\kappa$, while the third one represents the outcome of the capital buffer rule based on credit growth as conditioning variable $\left(\kappa_{t}^{c}\right)$.

requirements.

From figure 2 it clearly emerges the difference between $\kappa_{\min }=8 \%$ (that is the minimum capital currently required by Basel II) and $\kappa_{\min }=12 \%$. In both cases a turbulent period starts in the $5^{\text {th }}$ year (look at figure 2), first with a severe crisis and then with a period of stagnation that ends in the $7^{\text {th }}$ year of simulation. Observing the dynamics of the aggregate banks equity capital in figure 4 , it can be noticed that a tighter capital requirement $\left(\kappa_{\min }=12 \%\right)$ forces banks to raise their equity while when the requirement is lower $\left(\kappa_{\min }=8 \%\right)$ banks can match the credit demand with a lower level 

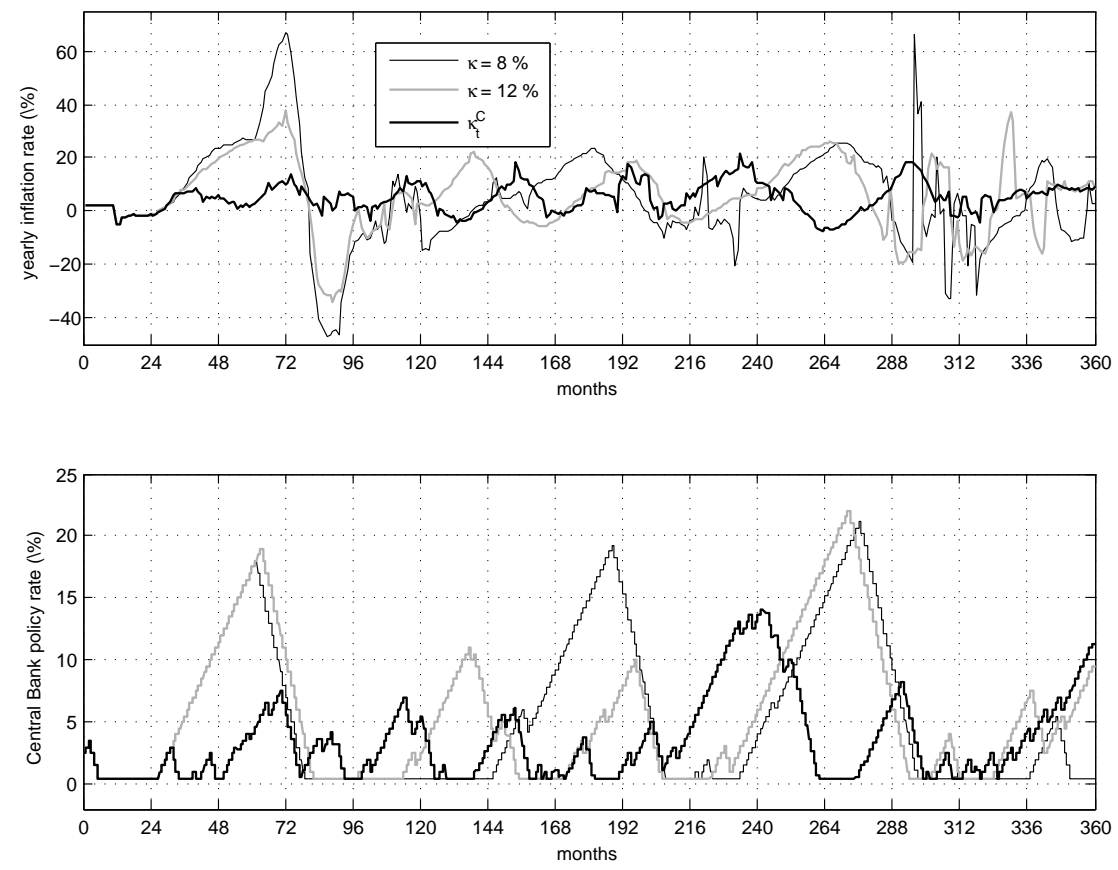

Fig. 3. Time evolution of yearly inflation and base interest rate. Two lines correspond to different fixed values for minimum capital requirement $\kappa$, while the third one represents the outcome of the capital buffer rule based on credit growth as conditioning variable $\left(\kappa_{t}^{c}\right)$.

of equity capital. The capital surplus (or buffer) owned by banks in the case of $\kappa_{\text {min }}=12 \%$ makes the difference when facing the following crisis starting in the $9^{\text {th }}$ year, allowing the economy to recover quickly from the recession by means of a injection of new credit money by the banking sector. On the other hand, when equity capital is too low, the banking system is not able to fuel the economy with new credit, even if capital requirement is looser, and the depression continues much deeper and for a much longer time. It is interesting to observe the clear bifurcation of the two time trajectories representing the total outstanding credit, emerging as a consequence of the $9^{t h}$ year crisis, and revealing the apparent paradox that banks will be much more "generous" 

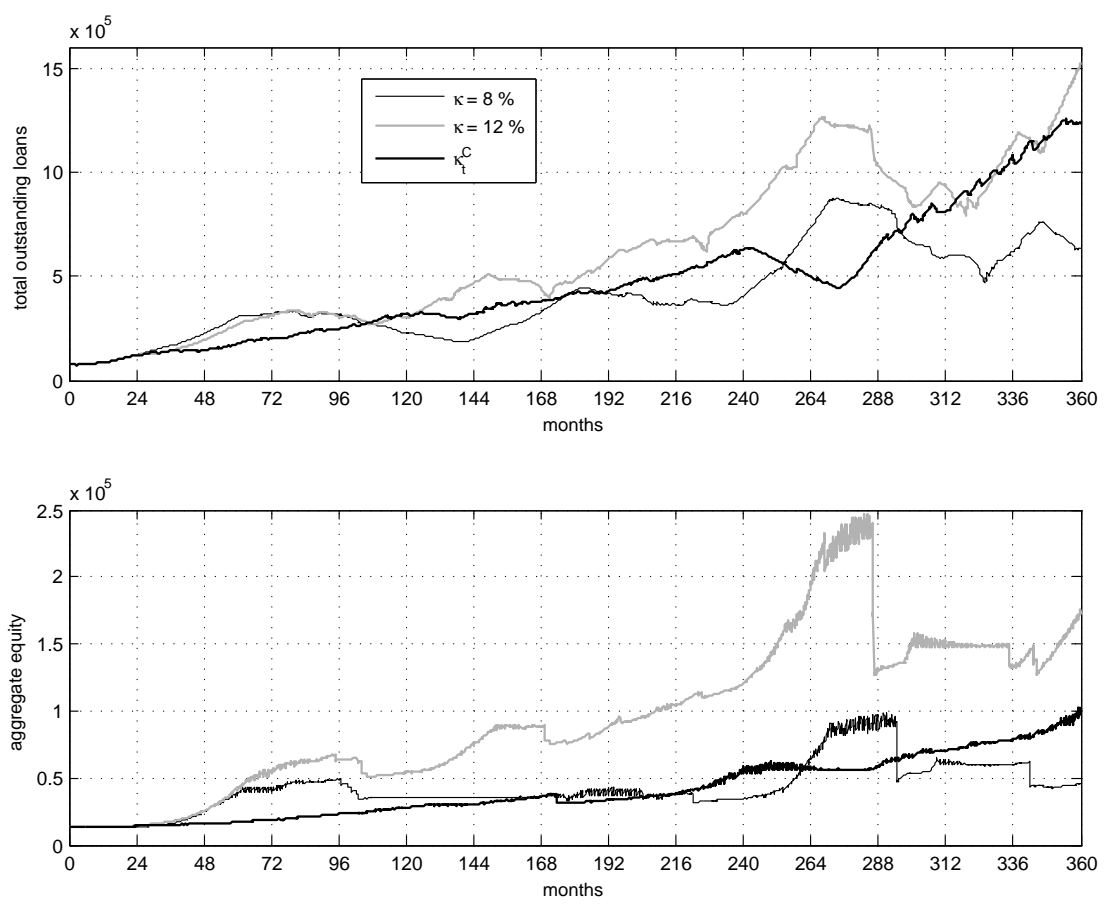

Fig. 4. Time evolution of total credit and aggregate banks equity capital. Two lines correspond to different fixed values for minimum capital requirement $\kappa$, while the third one represents the outcome of the capital buffer rule based on credit growth as conditioning variable $\left(\kappa_{t}^{c}\right)$.

lenders for the following 20 years in the case of higher capital requirement.

The lesson learned by this example is that having a capital buffer in bad times is useful. As extensively commented in the introduction, the same lesson seems to be shared by the main banking policy regulators, thus we present here the results of two computational experiments where two different rules to build-up capital buffers have been implemented. The first one uses the unemployment rate as a conditioning variable, as reported in eq. 9, while the second uses banks loans, as in eq. 10. 

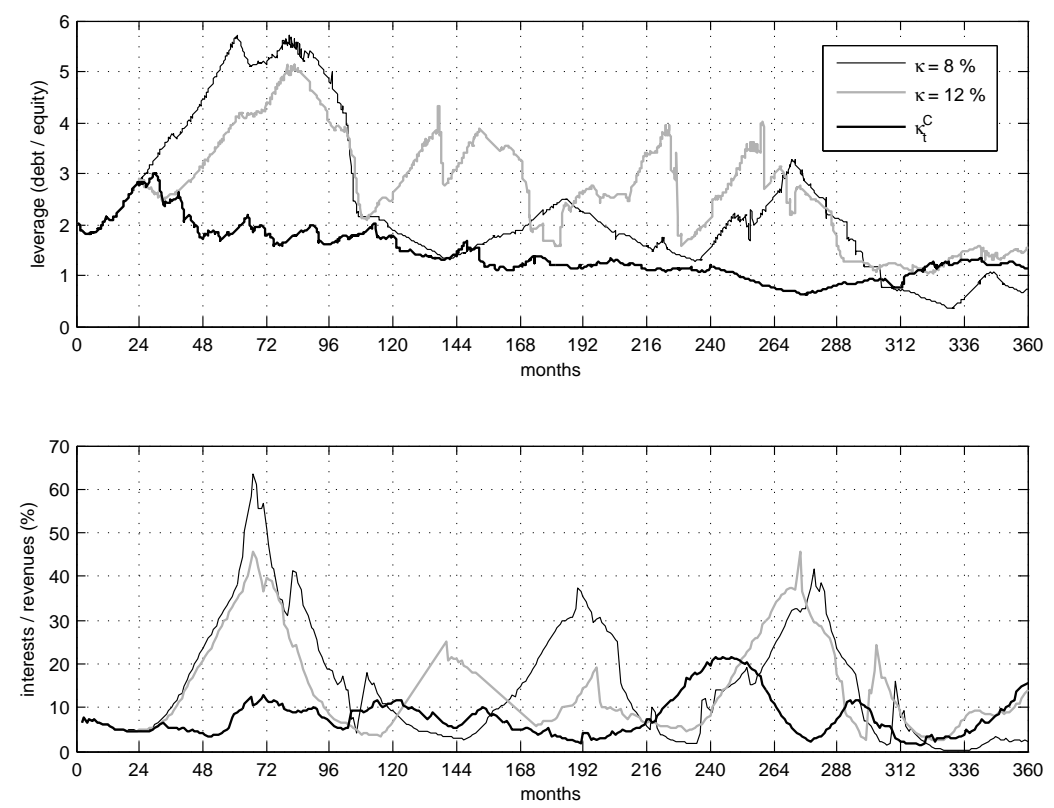

Fig. 5. Time evolution of firms financial fragility indicators. Two lines correspond to different fixed values for minimum capital requirement $\kappa$, while the third one represents the outcome of the capital buffer rule based on credit growth as conditioning variable $\left(\kappa_{t}^{c}\right)$.

The two rules seem both to have a positive impact on the economic performance. In particular, the capital buffer rule based on the unemployment rate (i.e., $\kappa_{t}^{u}$ ) improves all the economic indicators in the long run. These results confirm and extend preliminary explication discussed in Teglio et al (2012). Table 4 shows that in the case of $\kappa_{t}^{u}$ the average unemployment rate is lower than for fixed capital requirements, and the average output is higher. The interesting point about this result is that dynamic requirements $\kappa_{t}^{u}$, varying in a range from $8 \%$ to $12 \%$ with mean 11.34 , perform better that the two range extremes, including the highest one $(12 \%)$. So it is not true that tighter capital requirements are a better option overall, because it depends from the 


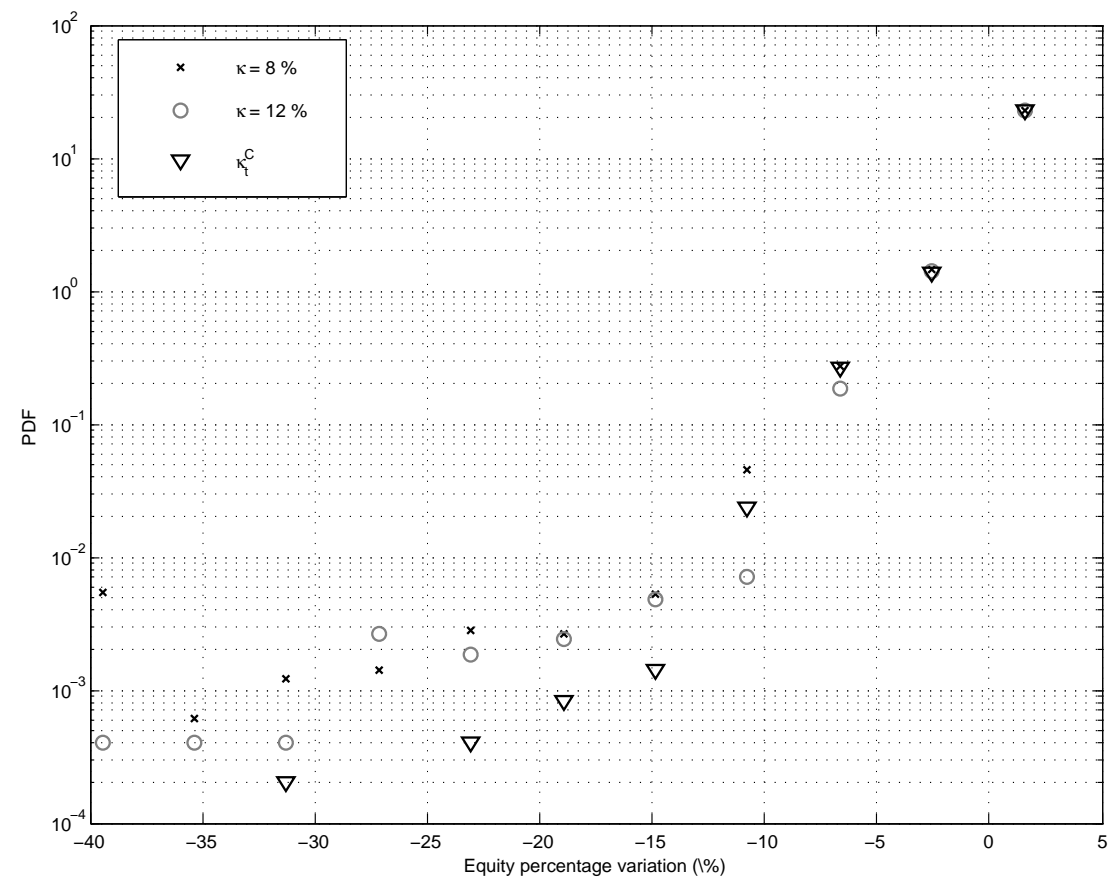

Fig. 6. Probability density function (PDF) estimation of the equity capital percentage variations for three different regulatory policies.

state of the economy. In some cases, according to our outcomes, relaxing the capital requirement is beneficial.

In order to analyze in more detail the effects of these policies, we plotted the time trajectories of the simulation with bank credit growth as a conditioning variable $\left(\right.$ case $\kappa_{t}^{c}$ ) along with the two extreme cases $\kappa=8 \%$ and $12 \%$ (for the seek of plots readability we omitted to superimpose the case of $\kappa_{t}^{c}$ ). Before looking at them, let us highlight the excellent performance of the "credit rule" $\kappa_{t}^{c}$. Whilst suffering in the first five years (see table 3 ) the economy of the "credit rule" is characterized by the best economic indicators: consumption, investments, unemployment rate, real wages, firms financial fragility, and others. Tables from 4 to 6 attest these results. The only apparently jarring 
note in this idyllic picture is banks equity, significantly lower than the rest of the cases. Moreover, from an overall glance at the presented plots it clearly appears that the economy is considerable more stable in the case of the "credit rule". In the following we try to interpret these outcomes.

First, let us note that the initial conditions are the same for all cases, and that banks are characterized at the beginning by a strong capitalization with equity equal to $20 \%$ of weighted assets. We remind also that banks raise their equity capital when the capital requirement constraint is binding, i.e., when they are not able to satisfy the credit demand because of the low equity. The "credit rule" states that when credit grows, capital requirement also grows, but it remains lower when credit stagnates. So, at the beginning of the $\kappa_{t}^{c}$ case simulation, there is no need for banks to raise the equity because of the low credit growth (see figure 4 ). In the other two cases $(\kappa=8 \%$ and $12 \%$ ), on the other hand, banks have to raise equity to match the growing credit demand. However, looking to figure 5, we can see how firms high borrowing raises the interest bill, increasing consequently firms bankruptcy risk. On the contrary, in the $\kappa_{t}^{c}$ case the situation is much more stable. In fact, the high level of firms debt ends in a big economic crash around month 100, accompanied by a quick deleveraging process. This crisis, strong for $\kappa=8 \%$ and milder for $\kappa=12 \%$, does not affect the the $\kappa_{t}^{c}$ case at all. When the "credit rule" rule is active, the total outstanding credit is growing much more smoothly. The same holds for banks equity, that is rarely affected by falls caused by insolvency bankruptcies (6). Illiquidity bankruptcies are more frequent but the banking system is not directly affected, remaining robust and propagating its robustness to the real economy.

Figure 6 compares banks equity variations considering the whole simulation set. The higher robustness of the banking sector in the case of $\kappa_{t}^{c}$ is therefore extended from a single simulation seed to the general case. In particular, it can be observed from the plot that the falls of banks equity are much more infrequent in case banks build up capital buffers according to the rule based on credit growth. These results tell us that lower aggregated values of outstanding bank loans and of banks equity capital do not have negative implications on the economy if credit is granted at the right time. In this sense, it seems to be desirable to have active (public) institutions in charge of ruling banks credit supply according to the macroeconomic conjuncture.

\section{Concluding remarks}

After the recent financial and economic crisis the Basel III global regulatory standard has been proposed in order to improve the resilience of the banking system. This new framework is oriented towards a more active support of 
macroeconomic policies, and presents a set of macro-prudential regulations with the objective to limit systemic risk. In particular, it has been identified the procyclical amplification of financial shocks through the banking system as a critical issue, and in order to cope with such procyclical dynamics new countercyclical capital buffers regulations has been proposed. The rational is to encourage banks to accumulate capital during good times and use it when the economic conditions are bad.

A coherent economic analysis has emerged from some previous works by the authors, where computational experiments were performed with the Eurace model. In particular, it has been shown that excessive bank leverages can drive economies into severe recession in the medium-long run. In this paper we implement into the model a mechanism to encourage banks to build up and release capital buffers, according to the overall economic conditions of the economy. As conditioning variables that set banks capital requirements, thus ruling the capital buffers build up and release phases, we use both the unemployment rate and aggregate banks loans.

Moreover, the setting of the model has been improved incorporating a new demand for firms investments that is based on the net present value (NPV) approach, which is one of the most popular methods used by managers to evaluate investments. Therefore, the new model for investments can be considered well grounded on a more realistic behavior of economic actors.

Results confirm an extend our previous studies, showing that loose capital requirements can affect the economic performance in the medium-long run, raising the financial fragility (or systemic risk) in the economic system and potentially triggering chains of firms insolvency bankruptcies. The situation is generally better when setting tighter capital requirements. Furthermore, results have shown that the dynamic regulation of capital requirements successfully stabilizes the economy and improves the main economic indicators. In particular, when the "credit rule" is adopted, the economic scenario seems to change in a significant way, showing a much more solid banking sector with a resulting positive effect on the real economy.

\section{Acknowledgement}

This work was carried out in conjunction with the Eurace project (EU IST FP6 STREP grant: 035086). AT acknowledges also the project Bancaja: P11A2010-17. 


\section{References}

Acharya VV (2009) A theory of systemic risk and design of prudential bank regulation. Journal of Financial Stability 5(3):224-255

Allen F, Gale D (2000) Bubbles and crises. Economic Journal 110(460):236-55

Andersen H (2011) Procyclical implications of basel ii: Can the cyclicality of capital requirements be contained? Journal of Financial Stability 7(3):138154

Antão P, Lacerda A (2011) Capital requirements under the credit risk-based framework. Journal of Banking \& Finance 35(6):1380-1390

BIS (2011) Basel III: A global regulatory framework for more resilient banks and banking systems. Tech. rep., Basel Committee on Banking Supervision, URL http://www.bis.org/publ/bcbs189.htm

Blum J, Hellwig M (1995) The macroeconomic implications of capital adequacy requirements for banks. European Economic Review 39(3-4):739-749

Borio C (2011) Rediscovering the macroeconomic roots of financial stability policy: journey, challenges and a way forward. Tech. rep., Bank for International Settlements Working Paper 354

Carroll CD (2001) A theory of the consumption function, with and without liquidity constraints. Journal of Economic Perspectives 15(3):23-45

Cecchetti SG, Li L (2008) Do capital adequacy requirements matter for monetary policy? Economic Inquiry 46(4):643-659

Chiarella C, Di Guilmi C (2011) The financial instability hypothesis: A stochastic microfoundation framework. Journal of Economic Dynamics \& Control 35(8):1151-1171

Cincotti S, Raberto M, Teglio A (2010) Credit money and macroeconomic instability in the agent-based model and simulator eurace. The Open-Access, Open-Assessment E-Journal 4(2010-26), URL http://dx.doi.org/10.5018/economics-ejournal.ja.2010-26

Cincotti S, Raberto M, Teglio A (2012) The Eurace macroeconomic model and simulator. In: Agent-based Dynamics, Norms, and Corporate Governance. The proceedings of the 16-th World Congress of the International Economic Association, Palgrave, vol II, forthcoming.

Deaton A (1992) Household saving in ldcs: credit markets, insurance and welfare. The Scandinavian Journal of Economics 94(2):253-273

Delli Gatti D, Di Guilmi C, Gaffeo E, Giulioni G, Gallegati M, Palestrini A (2005) A new approach to business fluctuations: heterogeneous interacting agents, scaling laws and financial fragility. Journal of Economic behavior \& organization 56(4):489-512

Delli Gatti D, Gallegati M, Greenwald BC, Russo A, Stiglitz JE (2009) Business fluctuations and bankruptcy avalanches in an evolving network economy. Journal of Economic behavior \& organization 4(2):195-212

Dosi G, Fagiolo G, Roventini A (2010) Schumpeter meeting keynes: A policyfriendly model of endogenous growth and business cycles. Journal of Economic Dynamics and Control 34(9):1748-1767 
Drehmann M, Borio C, Gambacorta L, Jiminez G, Trucharte C (2010) Countercyclical capital buffers: exploring options. Bis working papers, Bank for International Settlements

Fazzari SM, Ferri P, Greenberg E (2008) Cash flow, investment, and keynesminsky cycles. Journal of Economic Behavior \& Organization 65(3-4):555572

Gordy M (2009) First, do no harm a hippocratic approach to procyclicality in basel ii. Paper presented at the conference Procyclicality in the financial system, jointly organised by the Netherlands Bank and the Bretton Woods Committee

Graham J, Harvey C (2001) The theory and practice of corporate finance: evidence from the field. Journal of Financial Economics 60(2-3):187-243

Graham J, Harvey C (2002) How do CFOs make capital budgeting and capital structure decisions? Journal of Applied Corporate Finance 15(1):8-23

Heid F (2007) The cyclical effects of the basel ii capital requirements. Journal of Banking \& Finance 31(12):3885-3900

Hillier F, Lieberman G (1986) Introduction to Operations Research. McGrawHill

Kahneman D, Tversky A (1979) Prospect theory: an analysis of decision under risk. Econometrica 47(2):263-292

Myers S, Majluf N (1984) Corporate financing and investment decisions when firms have information that investors do not have. Journal of Financial Economics 13(2):187-221

Raberto M, Teglio A, Cincotti S (2008a) Integrating real and financial markets in an agent-based economic model: an application to monetary policy design. Computational Economics, forthcoming

Raberto M, Teglio A, Cincotti S (2008b) Prospect Theory Behavioral Assumptions in an Artificial Financial Economy, Lecture Notes in Economics and Mathematical Systems, vol 614, Springer, pp 55-66

Raberto M, Teglio A, Cincotti S (2011) Debt deleveraging and business cycles. an agent-based perspective. Economics Discussion Paper (2011-31), URL http://www.economics-ejournal.org/economics/discussionpapers/2011-31

Repullo R, Saurina J (2011) The countercyclical capital buffer of basel iii: A critical assessment. Cepr discussion papers, C.E.P.R. Discussion Papers

Repullo R, Saurina J, Trucharte C (2010) Mitigating the pro-cyclicality of basel ii. Economic Policy 25:659-702

Saunders A, Allen L (2010) Credit Risk. Measurement In and Out of the Financial Crisis. Wiley

Teglio A, Raberto M, Cincotti S (2009) Explaining equity excess return by means of an agent-based financial market, Lecture Notes in Economics and Mathematical Systems, vol 631, Springer Verlag, chap 12, pp 145-156

Teglio A, Raberto M, Cincotti S (2010a) Balance sheet approach to agentbased computational economics: The Eurace project. In: Combining Soft Computing and Statistical Methods in Data Analysis, Advances in Intelligent and Soft Computing, vol 77, Springer Berlin / Heidelberg, pp 603-610 
Teglio A, Raberto M, Cincotti S (2010b) Endogenous credit dynamics as source of business cycles in the Eurace model. In: Li Calzi M, Milone L, Pellizzari P (eds) Progress in Artificial Economics, Lecture Notes in Economics and Mathematical Systems, vol 645, pp 203-214

Teglio A, Raberto M, Cincotti S (2012) The impact of banks' capital adequacy regulation on the economic system: an agent-based approach. Advances in Complex Systems Forthcoming

Tesfatsion L, Judd K (2006) Agent-Based Computational Economics, Handbook of Computational Economics, vol 2. North Holland

Tversky A, Kahneman D (1992) Advances in prospect theory: cumulative representation of uncertainty. Journal of Risk and Uncertainty 5(4):297323

Yeh A, Twaddle J, Frith M (2005) Basel II: A new capital framework. Tech. rep., Reserve Bank of New Zealand: Bulletin, vol. 68, no. 3 